\title{
SUCCESSFUL TREATMENT OF CAPD PERITONITIS CAUSED BY MORAXELLA CATARRHALIS
}

\section{USPEŠNO LEČENJE MORAXELLA CATARRHALIS-OM PROUZROKOVANOG CAPD PERITONITISA

\author{
Dejan Pilčević
} \\ Klinika za nefrologiju, Vojno-medicinska akademija, Beograd, Srbija}

\begin{abstract}
Peritonitis remains a major complication of peritoneal dialysis which is usually caused by saprophytic gram positive microorganisms originated from skin. Here, I report an unusual case of peritonitis due to Moraxella catarrhalis.

A male, 59 age, on peritoneal dialysis modality because ESRD due to diabetic nephropathy was admitted to our hospital due to CAPD peritonitis. After initial empiric treatment and identification of this infrequent causer, he was submitted to two week antibiotic treatment with complete recovery and good prognosis.

Peritonitis is the major cause of peritoneal dialysis failure which requires prompt recognition of the causative agent for successful treatment.
\end{abstract}

Keywords: peritoneal dialysis, peritonitis, diabetic nephropathy, treatment

\section{SAŽETAK}

Peritonitis predstavlja najozbiljniju komplikaciju lečenja peritoneumskom dijalizom $i$ obično je prouzrokovan gram pozitivnim komensalnim mikroorganizmima sa kože. U našem radu prikazujemo slučaj peritonitisa izazvan neuobičajenim uzročnikom Moraxella catarrhalis.

Muškarac star 59 godina, na programu lečenja peritoneumskom dijalizom zbog terminalne bubrežne slabosti izazvane dijabetesnom nefropatijom primljen je u našu bolnicu zbog CAPD peritonitisa. Nakon inicijalno sprovedene empirijske terapije i identifikacije ovog retkog uzročnika, naredne dve sedmice je sprovedeno ciljano lečenje prema antibiogramu sa kompletnim oporavkom pacijenta.

Peritonitis kao najozbiljnija komplikacija peritoneumske dijalize zahteva brzu i optimalnu identifikaciju uzročnika radi uspešnog lečenja.

Ključne reči: peritoneumska dijaliza, peritonitis, dijabetesna nefropatija, lečenje

\section{INTRODUCTION}

Peritoneal dialysis is ESRD treatment modality complementary with hemodialysis and kidney transplantation, based on simultaneous daily exchanges over peritoneal catheter (1). The main complication of these home dialysis modality is peritonitis. Based on the latest reports of International Society for Peritoneal Dialysis, death outcome is presented in less than $5 \%$ of total peritonitis episodes, but indirectly it is contributing factor for death outcome in $16 \%$ of peritoneal dialysis patients (2). Also, peritonitis is strongly associated with significant morbidity- transient loss of ultrafiltration, possible permanent membrane damage and transfer to hemodialysis (3-5). The most frequent causers are gram positive organisms originated from the skin (coagulase negative staphylococci) and less often gram negative organisms and fungi (6). Here, I report a case of peritonitis caused by Moraxella species. Until now, on the basis of relevant literature data, there were only 8 published cases of peritonitis due to this pathogen (7-13). 


\section{CASE REPORT}

A insulin depended diabetic male, 59 age, on peritoneal dialysis over 12 months due to end-stage renal disease, was admitted to our hospital because of strong abdominal pain followed by cloudy peritoneal fluid. His medical history excluded previous episodes of peritonitis and exit site infections. He conducts four daily exchanges with fill volume of $2000 \mathrm{ml}$ (PET test showed $\mathrm{d} / \mathrm{p}$ creatinine 0.62 -low average transport status) - 3x1.36\%, with night exchange with $2.27 \%$ of glucose. He uses conventional solutions (Dianel $^{\oplus}$; Baxter), and he has satisfied parameters of dialysis adequacy -KT/V was 2.1, weekly creatinine clearance was 72.6 1/7 days; he also has preserved residual diuresis (approximately $1250-1500 \mathrm{ml} / 24$ hours).

Actually, initially analysis of blood sample showed Creactive protein level $129 \mathrm{mg} / \mathrm{dL}$, dialysis fluid showed 266 cell's elements and Gram stain of the fluid showed white blood cells. He was immediately started on empirical therapy -cefazolin and amikacin (our center specific initial treatment protocol for patients without residual renal function). After 48 hours, pains were reduced; effluent became purified with regression of fluid's WBC count (86 elements) when he discontinued aminoglycosides. Initial antibiotic susceptibility testing was unsuccessful due to the slow bacterial growth, but the culture was identified after 5 days as Moraxella catarrhalis (BacT/Alert). The organism was sensitive to ampicillin, amoxicillin/clavulanate, cefazolin, ceftazidime, ceftriaxone, erythromicin, trimethoprim/sulfamethoxazole and tetracycline, but it was resistant to vankomicin. Treatment with cefazolin was continued for 14 days which resulted in recovery of the patient's symptoms and complete healing of peritonitis (peritoneal fluid WBC count and culture became negative after 7 days, CRP level completely normalized after 10 days). We did not find the source of infection (nasal, sputum and exit site culture results were negative; US scan of the catheter's tunnel and X ray of lungs were correct). Repeated cultures of peritoneal fluid over the next 3 months have remained negative. Patient was continued on CAPD in good clinical condition.

\section{DISCUSSION}

Moraxella species are gram negative, aerobic catalase negative, oxidase-positive diploccocci which were first described in 1896. Human beings are exclusive hosts of this organism which is normally present in the oropharynx, mucous membranes, skin, and genital tract - almost 75\% of children and $1-3 \%$ of healthy adults are carriers of the bacterium (14). These organisms usually cause respiratory tract infections but can also cause bacteraemia, meningitis, suppurative arthritis, osteomyelitis, endocarditis, keratitis, periorbital cellulitis and urethritis (15-20).

Until now, there were only 8 published cases of peritonitis due to this pathogen (7-13). Identification of these organisms requires culture on blood or chocolate agar plates and usually takes 24 to 48 hrs. Most strains (>90\%) are susceptible to penicillin with exception of Moraxella catarrhalis which is susceptible to amoxicillin-clavulanate, expanded-spectrum or broad-spectrum cephalosporins, tetracyclines, rifampin and erythromycin $(15-18,21)$. Empirical choice of antibiotic therapy with cephalosporins which is recommended by the International Society of Peritoneal Dialysis guidelines/recommendations is sufficient and appropriate for the initial treatment of Moraxella related peritonitis (1). Further treatment should be continued with an appropriate antibiotic for 14 days, based on ISPD recommendations.

\section{CONCLUSIONS}

Peritonitis remains a most serious complication of peritoneal dialysis. Accurate and prompt identification of the causative organism, along with previous starting of appropriate empiric treatment, is necessary for positive outcome of this complication of peritoneal dialysis patients.

I have presented a case of infrequent Moraxella catarrhalis peritonitis and commented on the methods of diagnosis and appropriate treatment without catheter removal.

\section{REFERENCES}

1. Lameire N, Van Biesen W, Vanholder R. The role of peritoneal dialysis as first modality in an integrative approach to patients with end -stage renal disease. Peritoneal Dialysis International. 2000;20(2):S134-141.

2. Li PK, Szeto CC, Piraino B, et al. ISPD Peritonitis Recommendations: 2016 Update on Prevention and Treatment. Perit Dial Int. 2016;36:481-508.

3. Holley JL, Praino BM. Complications of peritoneal dialysis: Diagnosis and management. Semin Dial. 1990;3:245.

4. Woodrow G, Turney JH, Brownjohn AM. Technique failure in peritoneal dialysis and its impact on patient survival. Perit Dial Int. 1997;17:360.

5. Perez Fontan M, Rodriguez-Carmona A, GarciaNaveiro R, et al. Peritonitis-related mortality in patients undergoing chronic peritoneal dialysis. Perit Dial Int. 2005;25:274.

6. Akoh JA. Peritoneal dialysis associated infections: An update on diagnosis and management. World J Nephrol. 2012;1(4):106-122.

7. MacArthru RD. Branhamella Catarrhalis peritonitis in two continuous ambulatory peritoneal dialysis patients. Perit Dial Int. 1990;10:169-71.

8. Dadone C, Redaelli B. Branhamella Catarrhalis peritonitis in CAPD: An avoidable complication. Perit Dial Int. 1991;11:185. 
9. Contreras MR, Ash SR, Swick SD, Grutzner J. Peritonitis due to Moraxella Catarrhalis(Branhamella) in a diabetic patient receiving peritoneal dialysis. South Med J. 1993;86:589-90.

10. Ragnaud JM, Bezian MC, Marceau DM, Wone C. Treatment of peritonitis in continuous ambulatory peritoneal dialysis with intraperitoneal ceftriaxone. Pathol Biol. 1988;36(5):552-56.

11. Fandos JMG, Manez MB. Peritonitis Due to Moraxella Non Liquefaciens. Perit Dial Int. 2014; 34(6): 674-675.

12. Badrising S, Bakker L, Lobatto S, Van Es A. Peritonitis in a Peritoneal Dialysis Patient Due to Rhizobium radiobacter and Moraxella osleonsis: Case Report and Literature Review. Perit Dial Int. 2014; 34(7): 813-815.

13. Sadjadi SA, Obedoza P, Annamarju P. Moraxella Catarrhalis peritonitis. Am J Case Rep. 2012;13:19-21.

14. Verduin CM, Hol C, Fleer A, at al. Moraxella catarrhalis: from emerging to established pathogen. Clinical Microbiology Reviews 2002;15(1):125-144.

15. Ryan KJ, Ray CG. Sherris Medical Microbiology: An Introduction to Infectious Disease. 4th ed. New York, McGraw-Hill; 2004.
16. Garrity GM, Brenner DJ, Krieg NR and Staley JT (Eds.). Bergey's Manual of Systematic Bacteriology. 2nd ed. New York: Springer; 2005.

17. Murray PR, Baron EJ, Jorgensen JH,Landry ML and Pfaller MA (Eds.). Manual of Clinical Microbiology. 9th ed. Washington: ASM Press; 2007.

18. Buchanan BK. Moraxella, branhamella, Kingella and Aeikenella. In: Balows A. and Duerden BI (Eds).Topley and Wilson's Microbiology and Microbial Infections. 1998. P1139-46.

19. Tritton D, Watts T, Sieratzki JS. Peri-orbital cellulitis and sepsis by Branhamella catarrhalis. Eur J Pediatr. 1998;157(7):611-2.

20. Abdolrasouli A, Amin A, Baharsefat M, et al. Moraxella catarrhalis associated with acute urethritis imitating gonorrhoea acquired by oral-genital contact. Int J STD AIDS. Aug. 2007;18(8):579-80.

21. Jorgensen JH, Doern GV, Maher LA, et al. Antimicrobial resistance among respiratory isolates of Haemophilus influenzae, Moraxella catarrhalis, and Streptococcus pneumoniae in the United States. Antimicrobial Agents and Chemotherapy. 1990;34(11):2075-2080. 